\title{
Efficacy of Photobiomodulation and Vitamin D on Odontogenic Activity of Human Dental Pulp Stem Cells
}

\author{
Latifa M. Abdelgawad ${ }^{* \mathbb{D}}$, Nehal Salah², Dina Sabry³, Marwa Abdelgwad ${ }^{4}$ \\ 1Professor of Medical Laser Applications Department, National Institute of Laser Enhanced Sciences (NILES), Cairo \\ University, Cairo, Egypt \\ ${ }^{2}$ Medical Laser Applications Department, National Institute of Laser Enhanced Sciences (NILES), Cairo University, Cairo, \\ Egypt \\ ${ }^{3}$ Professor of Medical Biochemistry and Molecular Biology, Faculty of Medicine, Cairo University, Cairo, Egypt \\ ${ }^{4}$ Lecturer of Medical Biochemistry and Molecular Biology, Faculty of Medicine, Cairo University, Cairo, Egypt
}

\author{
*Correspondence to \\ Latifa M. Abdelgawad, \\ Professor of Medical Laser \\ Applications Department, \\ National Institute of Laser \\ Enhanced Sciences (NILES), \\ Cairo University, Cairo, Egypt \\ Tel: 00201005215402 ; \\ Fax:002023570848; \\ Email: latifa@niles.edu.eg
}

Received: August 8, 2020 Accepted: September 5, 2020 epublished: June 24, 2021

\begin{abstract}
Introduction: The regeneration of dental pulp tissue using human dental pulp stem cells (HDPSCs) has attracted increasing attention in recent years. Recent studies have suggested that several factors such as photobiomodulation (PBM) and vitamin D affect the proliferation and differentiation of HDPSCs. Therefore, the present study evaluated the effects of PBM and vitamin D on odontogenic differentiation of HDPSCs for dentin -like tissue formation

Methods: HDPSCs were collected, isolated, and characterized and then divided into six groups: group I, control; group II, vitamin D $\left(10^{-7} \mathrm{Mol}\right)$; group III, irradiation at $1 \mathrm{~J} / \mathrm{cm}^{2}$ of $810 \mathrm{~nm}$ diode laser; group IV, irradiation at $1 \mathrm{~J} / \mathrm{cm}^{2}$ and culture with vitamin D; group $\mathrm{V}$, irradiation at $2 \mathrm{~J} / \mathrm{cm}^{2}$, and group $\mathrm{VI}$, irradiation at $2 \mathrm{~J} / \mathrm{cm}^{2}$ and culture with vitamin D, cell viability assay was measured through MTT. Alkaline phosphatase (ALP) enzyme activity and mRNA levels of vascular endothelial growth factor (VEGF), bone morphogenic protein-2 (BMP-2), and dentin sialophosphoprotein (DSPP) were also assessed.

Results: PBM at 1 and $2 \mathrm{~J} / \mathrm{cm}^{2}$ combined with vitamin D significantly promoted HDPSCs proliferation through MTT assay and odontogenic differentiation through gene expression of VEGF, BMP-2, and DSPP levels $(P<0.0001)$.

Conclusion: PBM at $2 \mathrm{~J} / \mathrm{cm}^{2}$ combined with vitamin D enhanced the HDPSCs proliferation and odontogenic differentiation and thus could be a novel strategy for dentin regeneration in dentistry. Keywords: Photobiomodulation (PBM); Vitamin D; Human dental pulp stem cells (HDPSCs); VEGF; BMP-2; DSPP.
\end{abstract}

\section{Introduction}

Functional pulp regeneration is of great relevance in the treatment of pulp diseases and tissue engineering. In this regard, human dental pulp stem cells (HDPSCs) have the clonogenic capacity and are considered as odontogenic progenitor cells. ${ }^{1}$ These cells are highly proliferated and capable of differentiating into multiple cell lines (odontogenic, osteogenic, and adipogenic), suggesting a suitable cell source for tissue engineering. ${ }^{2}$ HDPSCs play an important role in dentinogenesis by differentiating into odontoblasts and enabling dentin and enamel mineralization through unending and collaborative interactions with dental epithelial stem cells. $^{2}$ Photobiomodulation (PBM) has been known for the previous three centuries to alleviate pain and inflammation and ${ }^{3}$ improve wound healing ${ }^{3,4}$ and repair of tissue. ${ }^{5}$ Previous studies have found that cell proliferation and differentiation and odontogenic, osteogenic, and angiogenic gene expression may be stimulated by PBM. ${ }^{6}$ It has also been established that vitamin $\mathrm{D}$ causes osteogenic differentiation in the human dental pulp (HDP) and dental follicle cells. ${ }^{7}$ Furthermore, vitamin $\mathrm{D}$ has been demonstrated that it has an efficient role in reinforcing odontogenesis and dentin regeneration. ${ }^{8}$ During tooth development, bone morphogenic protein-2 (BMP-2) signaling has a major role in monitoring dentin sialophosphoprotein (DSPP) expression which occurs in the secretory stage after BMP-2 expression where the activity of dentin mineralization in the bell stage becomes highly active. ${ }^{9}$ Also, during the differentiation and maturation phase of odontoblasts, BMP-2 and VEGF were identified. ${ }^{10}$ The VEGF protein family regulates 
vascularization as well as angiogenesis. ${ }^{3}$ Also, it enhances microvessel-like endothelial cells to proliferate, migrate, and alter the structure of gene expression. ${ }^{4,6}$ Therefore, the main purpose of this research was to evaluate the effect of PBM using $810 \mathrm{~nm}$ diode laser and vitamin D on odontogenic activity of HDPSCs via MTT assay, alkaline phosphatase (ALP) measurements, and gene expression of VEGF, BMP-2, and DSPP.

\section{Materials and Methods}

Human Dental Pulp Stem Cells Isolation and Culturing Fifteen sound impacted third molars were extracted from healthy adult male patients (18-32 years old) at the outpatients' clinic, Cairo University, after their informed consent. Therefore, a relatively narrow age range of patients was chosen to reduce the aging effects of HDPSCs. The extracted teeth were placed on ice in phosphate buffer saline (PBS) (Thermo Scientific, USA), and were then transmitted to the tissue culture unit directly.

Primary cells were isolated and cultured from the extracted impacted molars as previously described by three authors. ${ }^{11-13}$ Briefly, HDP tissues from the pulp chamber and the root canal were collected and then digested with $0.3 \mathrm{mg}$ collagenase type II (SERVA, Germany) enzyme for 2 hours at $37^{\circ} \mathrm{C}$. Then, the cell strainer $(70-\mu \mathrm{m})$ was infiltrated for the suspension of the single cell and the centrifugation at $60 \mathrm{~g}$ for 8 minutes was used for the collection of the cells which were suspended in the plating medium. The maintenance of cells was done in RPMI-1640 with L-glutamine (BioWhittaker', Lonza, USA cat\#12-702F) with $10 \%$ fetal bovine serum (LSP ${ }^{\circledast}$, cat\#S-001B-BR) and $1 \%$ penicillin/streptomycin (Biowest ${ }^{\oplus}$ USA, cat\# L0018-100) at $37^{\circ} \mathrm{C}$ in a $5 \% \mathrm{CO} 2$ incubator. Every 3 days, the culture medium was replaced by another one until $80 \%-90 \%$ confluence for 3 passages. For odontogenic differentiation, the plating medium was supplemented with $50 \mu \mathrm{g} / \mathrm{mL}$ ascorbic acid, $5 \mathrm{~mL} / \mathrm{Mol}$ $\beta$-glycerophosphate, and $10 \mathrm{mM}$ dexamethasone, all from Sigma-Aldrich. Every 3 days, the media were changed. ${ }^{13}$

\section{HDPSCs Characterization}

\section{Phenotypical Characterization of HDPSCs}

Subsequent culture of HDPSCs was examined under an inverted microscope (Leica ${ }^{\oplus}$, Germany) to confirm the shape and special characters (plastic adherence, spindle fusiform shape) of the stem cells. ${ }^{8}$

\section{Immunological Characterization of HDPSCs}

According to the International Society of Cell Therapy Criteria for human Stem Cells, ${ }^{14}$ fluorescence-activated cell sorting analysis was used to confirm surface antigens specific to CD105 (R\&D Systems, USA; cat \#, FAB1320F-025), and stem cells marker as CD29 (R\&D Systems, USA cat \#FAB2405P-025) and was negative to CD 45 (R\&D Systems, USA; cat \# FAB114A), excluding hematopoietic, endothelial cells.

\section{Vitamin D Preparation}

An active form of vitamin D3 (1,25-(OH)2) (cholecalciferol [oily form] (PH, Eur, India) was used in the study, with dose of $10^{-7} \mathrm{Mol}$, and distributed in six wells as $10000 \mathrm{I} . \mathrm{U}$ but in 96 wells as 1000 I.U. $^{8}$

\section{Study Design}

Ninety-six well tissue culture plates of HDPSCs were equally divided into six groups at the third passage as a follow, group I, control group without irradiation; group II, vitamin D $\left(10^{-7} \mathrm{Mol}\right)$; group III, irradiation at $1 \mathrm{~J} / \mathrm{cm}^{2}$ of $810 \mathrm{~nm}$ diode laser; group IV, irradiation at $1 \mathrm{~J} / \mathrm{cm}^{2}$ and culture with vitamin $\mathrm{D}$; group $\mathrm{V}$, irradiation at $2 \mathrm{~J} /$ $\mathrm{cm}^{2}$, and group VI, irradiation at $2 \mathrm{~J} / \mathrm{cm}^{2}$ and culture with vitamin $\mathrm{D}$.

\section{Laser Irradiation}

HDPSCs were irradiated with $810 \mathrm{~nm}$ diode laser (Denlase, China) in a continuous wave mode and output power of $100 \mathrm{~mW}$ and irradiation at $1 \mathrm{~J} / \mathrm{cm}^{2}$ and $2 \mathrm{~J} / \mathrm{cm}^{2}$. Cells were double irradiated (at 0,48 hours) with a laser probe fixed perpendicular to each plate and irradiation was carried out in dark conditions.

To avoid laser over exposure and scattering effect, the cells were distributed as there were empty wells between seeded well cells and the culture dishes were wrapped within the dark paper sheets with a hole of a diameter corresponding to the diameter of the laser spot area of the handpiece. ${ }^{6}$

\section{Cell Viability Assay}

MTT assay was used at 24, 48, 72, and 96 hours to analyze the cell viability of HDPSCs. According to the manufacturer's instructions (Sigma-Aldrich Co.), for 4 hours to 6 hours, the MTT reagent (3-[4, 5-dimethylthiazol-2-yl]-2, 5-diphenyl tetrazolium bromide) was applied to the measured cell wells $\left(1 \times 10^{3}\right)$. Once the purple precipitate was obvious, the detergent reagent $(100 \mu \mathrm{L}$ per well) was used to produce the soluble formazan dye. The covered plates were kept in the dark for 2 to 4 hours. The absorption in each well was evaluated with an ELISA reader plate (Dynatech MRX 5000; Dynex, Chantilly, VA) at $450 \mathrm{~nm} \cdot{ }^{15}$

\section{Alkaline Phosphatase Assay}

Ninety-six well culture plates for each time point $(0$, 7,14 , and 21 days) were seeded with $1 \times 10^{3}$ cells/well, homogenized in $50-\mu \mathrm{L}$ assay buffer, centrifuged for 3 minutes. Alkaline Phosphatase Assay Kit (Amplite ${ }^{\mathrm{Tm}}$ AAT Bioquest, Inc., USA cat\# 11950) was used by adding para-nitrophenylphosphate, a chromogenic phosphatase substrate, and then incubated at $37^{\circ} \mathrm{C}$ for $10-30$ minutes and measured levels of ALP documented in kilo unit $(\mathrm{KU}) / 100 \mathrm{~mL}$. Measurement of absorbance occurred at a wavelength of $400 \mathrm{~nm}$, and the amount of ALP in the cells was normalized against total protein content. ${ }^{16}$ 


\section{Alizarin Red S Staining}

Calcium deposits as end product of the odontogenic differentiation of HDPSCs was measured using alizarin red S staining (ARS) on day 21. HDPSCs were stained with a solution of $2 \%$ ARS (Bio Basic INC., Canada) for 15 minutes at a room temperature and washed with distilled water. $^{17}$

Quantitative RT-PCR for Odontogenic Genes (VEGF, BMP-2, And DSPP)

Total cellular RNA for VEGF, BMP-2 and DSPP were extracted using GF-1 Nucleic Acid Extraction Kits (Vivantis ${ }^{\oplus}$ Technologies, USA, cat\#GF-TR-050) and reverse transcribed using a complementary DNA master (SensiFAST $^{\mathrm{Tm}}$ One-Step Kit, USA, cat \# PI-50217 V).

PCR assays were conducted according to the manufacturer protocol in real-time PCR device (StepOne ${ }^{\mathrm{Tm}}$ Applied Biosystems, USA).

The RT reaction was followed by a real-time PCR with a SYBR Green assay performed on an Applied Biosystems (StepOne $^{\text {tw }}$ System, SDS software version 2.1 and RQ Manager 1.2). GAPDH was used as an endogenous reference control gene for normalization control. ${ }^{18}$

The primers of BMP-2, VEGF, DSPP and GAPDH genes were as follows:

DSPP, F: CAGTGATGAATCTAATGG, R:

CTGATTTGCTGCTGTCTGAC;

BMP-2, F: GGAACGGACATTCGGTCCTT, R:

AGTCCGTCTAAGAAGCACGC;

VEGF, F: CGGGAACCAGATCTCTCACC, R:

AAAATGGCGAATCCAATTCC; GAPDH,

F: TGCACCACCAACTGCTTAGC, R:

CCCCACGGCCATCA

\section{Statistical Analysis}

The results were replicated at least 3 times, and the data were displayed as mean \pm standard mean deviation. Data analysis was done by student $t$ test testing two data groups or one-way variance analysis with Tukey's post-hoc test for multiple data groups using GraphPad Prism version 7 (GraphPad Software, Inc. La Jolla, CA, USA). Differences between groups were considered statistically significant when $P$ value $<0.05$.

\section{Results}

\section{HDPSCs Characterization}

Phenotypical characterization of HDPSCs was assessed under an inverted microscope as a fusiform like cells as shown in in Figure 1. Immunological characterization was assessed as HDPSCs were negative to CD 45 surface antigen, positive to CD 29 surface antigen, and positive to CD105, as shown in Figure 1.

\section{Cell Viability Via MTT assay}

As illustrated in Figure 2, It was measured at 24, 48, 72 , and 96 hours. It showed that, after laser irradiation of $1 \mathrm{~J} / \mathrm{cm}^{2}$ and $2 \mathrm{~J} / \mathrm{cm}^{2}$, MTT activity had a statistically significant increase at 24,72, and 96 hours compared to the control group $(P=0.005)$. Moreover, there was a significant difference between groups III and V $(P<0.05)$ with the highest values of group $\mathrm{V}$, giving the idea that laser irradiation at $2 \mathrm{~J} / \mathrm{cm}^{2}$ increases proliferation of HDPSCs compared to laser irradiation at $1 \mathrm{~J} / \mathrm{cm}^{2}$. However, a significant value was obtained in the group with laser irradiation at $2 \mathrm{~J} / \mathrm{cm}^{2}$ and culture with vitamin $\mathrm{D}$ against vitamin $\mathrm{D}$ alone $(P<0.0001)$. These results confirmed a synergistic effect of $\mathrm{PBM}$ and vitamin $\mathrm{D}$ in
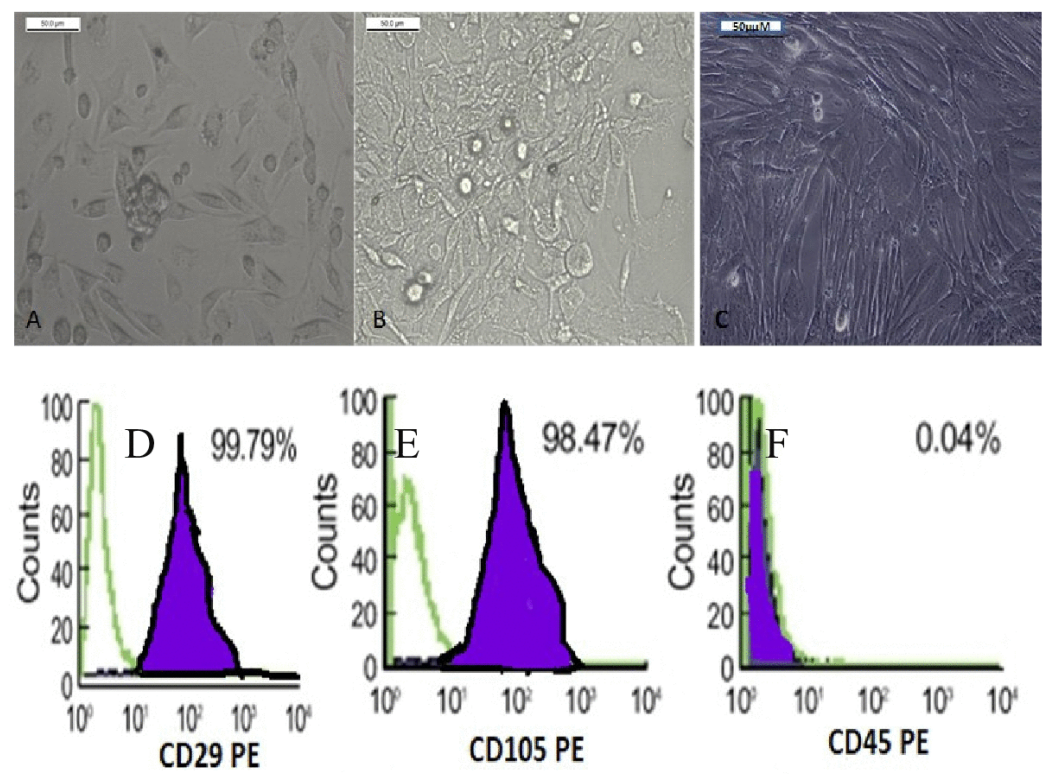

Figure 1. Characterization of HDPSCs; phenotypical characterization (upper section) (A, B and C) and immunological characterization (lower section); (D, E and F) 
enhancing proliferation of HDPSCs.

\section{ALP Enzyme Activity}

On day 7, There was no statistically significant difference between groups with laser irradiation of $1 \mathrm{~J} / \mathrm{cm}^{2}$ or that with culture of vitamin $\mathrm{D}$ and the control group, while significant values were observed in $1 \mathrm{~J} / \mathrm{cm}^{2}+$ vitamin $\mathrm{D}$, $2 \mathrm{~J} / \mathrm{cm}^{2}$, and $2 \mathrm{~J} / \mathrm{cm}^{2}+$ vitamin D groups compared to the control group $(P<0.05)$.

Moreover, on day 14, a highly significant difference was observed in the $2 \mathrm{~J} / \mathrm{cm}^{2}$ laser irradiated group and those with culture with vitamin $\mathrm{D}$ compared to the control and vitamin $\mathrm{D}$ alone groups $(P<0.001)$.

On day 21, the group with laser irradiation of $2 \mathrm{~J} / \mathrm{cm}^{2}$ showed a significant difference compared to the group with $1 \mathrm{~J} / \mathrm{cm}^{2}$ irradiation $(P<0.001)$. However, the laser irradiation combined with vitamin $\mathrm{D}$ groups (groups IV and VI) also showed a significant difference $(P<0.0001)$ that confirmed the synergistic effect of vitamin $D$ with PBM on HDPSCs (Figure 3).

Alizarin Red S Staining

As shown in Figure 4, Mineralized nodules were formed in all groups with various degrees of stain intensity reflecting their variable calcium content. However, group $\mathrm{VI}\left(2 \mathrm{~J} / \mathrm{cm}^{2}+\right.$ vitamin D) showed highest calcified nodules, which deeply stained than other groups.
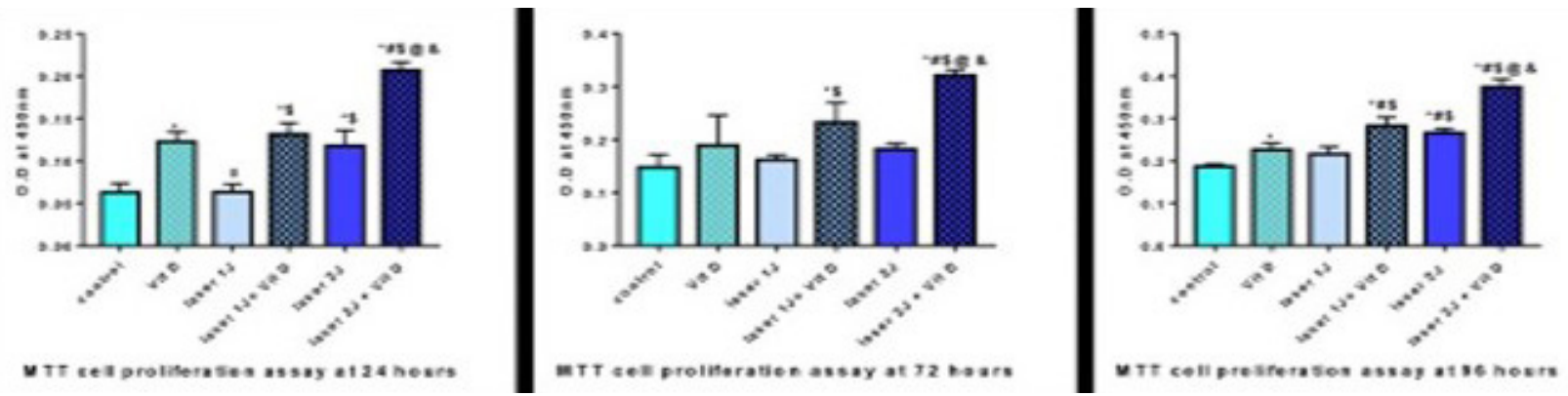

Figure 2. ALP activity levels measured at 14 days and 21 days with a highly significant difference between the $2 \mathrm{~J} / \mathrm{cm}^{2}$ group compared to the $1 \mathrm{~J} / \mathrm{cm}^{2}(P<0.001)$ on day 21 . Moreover, the $2 \mathrm{~J} / \mathrm{cm}^{2}$ and culture with vitamin $\mathrm{D}$ group showed highly statistically significant difference than the control group $(P<0.0001)$.
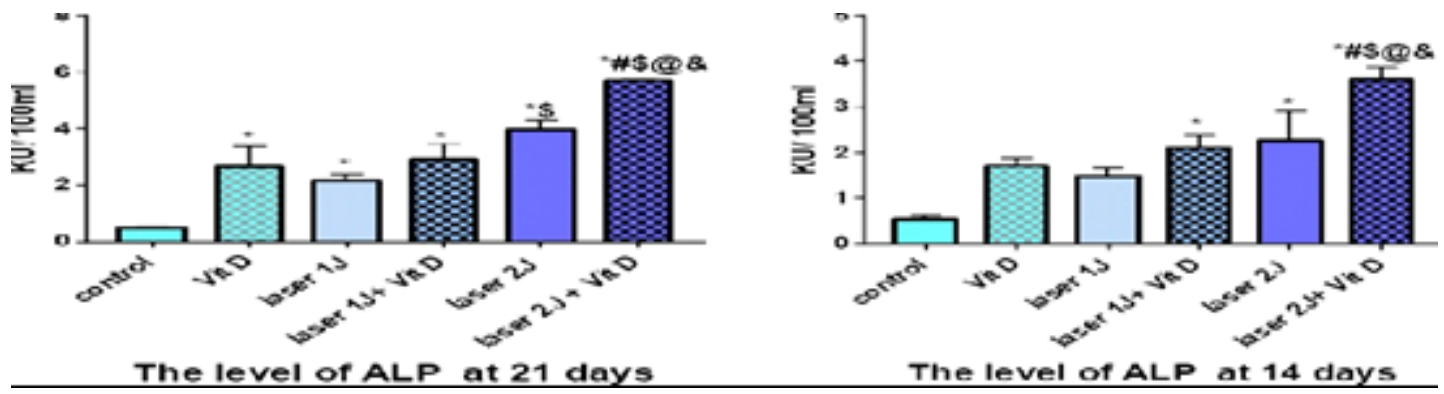

Figure 3. Alizarin Red stain of HDPSCs of different study groups on day 21 under microscope with a magnification of X200.Alizarin red stain deeply stains calcium nodules formed after odontogenic differentiation where A: for control group, B: for vitamin D only group, C: for group $1 \mathrm{~J} / \mathrm{cm}^{2}$, D: for $1 \mathrm{~J} / \mathrm{cm}^{2}+$ vitamin D, E: for $2 \mathrm{~J} / \mathrm{cm} 2$ group, F: group of vitamin D and $2 \mathrm{~J} / \mathrm{cm}^{2}$.

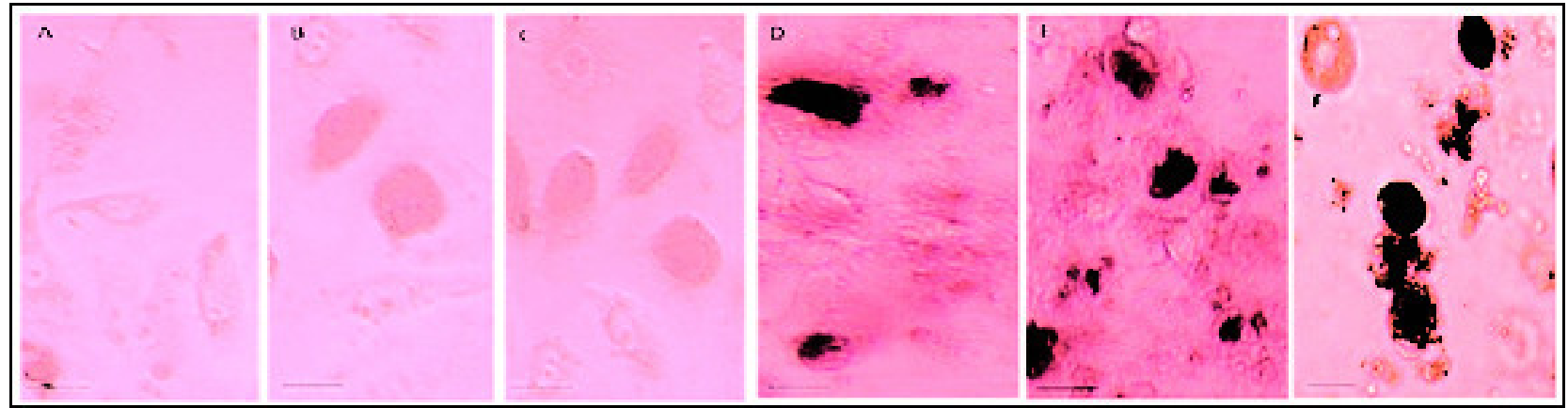

Figure 4. DSPP, BMP-2 and VEGF genes expression with the highest values in group VI ( $2 \mathrm{~J} / \mathrm{cm}^{2}+$ vitamin D). Data were expressed as mean \pm SD; $P$ value $<0.05$ was significant. $\left(^{*}\right)$ denotes significant difference versus control. (\#) denotes significant difference versus vitamin $D$. (\$) denotes significant difference versus laser $1 \mathrm{~J} / \mathrm{cm}^{2}$. (@) denotes significant difference versus laser $1 \mathrm{~J} / \mathrm{cm}^{2}+$ vitamin D. 
Quantitative RT-PCR for Odontogenic Genes (VEGF, BMP-2, and DSPP)

$V E G F$

VEGF plays an important role in angiogenesis and maintains odontoblast function. When measured on day 21 , it showed a statistically significant difference between all groups $(P<0.0001)$, especially groups irradiated with $2 \mathrm{~J} / \mathrm{cm}^{2}$ than those that were irradiated at $1 \mathrm{~J} / \mathrm{cm}^{2}$. It also showed a significant difference in group with laser irradiation at $2 \mathrm{~J} / \mathrm{cm}^{2}$ and culture with vitamin $\mathrm{D}$ than in group V (laser irradiation only at $\left.2 \mathrm{~J} / \mathrm{cm}^{2}\right)(P<0.0001)$.

Data analyzed showed that groups of vitamin $\mathrm{D}$ combined with PBM showed higher significance than groups with PBM only or vitamin D alone (Figure 5).

\section{$B M P-2$}

BMP-2 reinforces secondary dentin bridge formation through the up-regulation of DSPP expression. Similar results as those of VEGF were obtained from BMP-2 gene when measured at the end of the study $(P<0.0001)$ (Figure 5).

\section{DSPP}

The late dentin mineralization marker was measured on day 21 , and it showed a statistically significant difference between groups $(P<0.0001)$. However, with groups of laser irradiation at $2 \mathrm{~J} / \mathrm{cm}^{2}$ (groups $\mathrm{V}, \mathrm{VI}$ ), there were statistically different values against the control and vitamin $\mathrm{D}$ groups $(P=0.0001)$. However, with groups of laser irradiation at $2 \mathrm{~J} / \mathrm{cm}^{2}$ (groups $\mathrm{V}, \mathrm{VI}$ ), there were statistically different values against the control and vitamin D groups $(P=0.0001)$ (Figure 5).

\section{Discussion}

Dentinogenesis and angiogenesis are the two fundamental

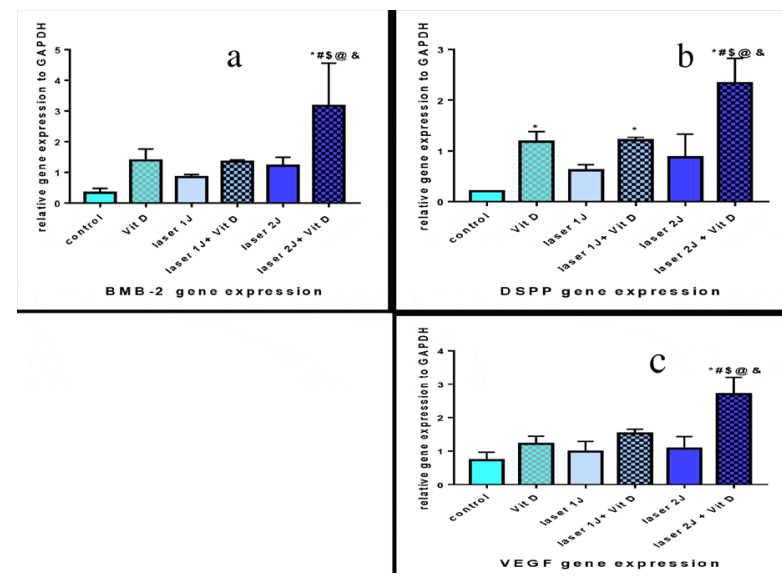

Figure 5. DSPP, BMP-2 andVEGF genes expression with the highest values in group VI $\left(2 \mathrm{~J} / \mathrm{cm}^{2}+\right.$ vitamin D). Data were expressed as mean \pm SD; P-value $<0.05$ was significant. $\left(^{*}\right)$ denotes significant difference versus control. (\#) denotes significant difference versus vitamin D. (\$) denotes significant difference versus laser $1 \mathrm{~J} / \mathrm{cm}^{2}$. (@) denotes significant difference versus laser $1 \mathrm{~J} / \mathrm{cm}^{2}+$ vitamin D. procedures of tooth repair and regeneration. ${ }^{19}$ Therefore, the present research focused on the role of PBM and vitamin $\mathrm{D}$ in both processes. The deficiency of vitamin $\mathrm{D}$ might lead to the unmineralized dental structure as a result of hypocalcification of enamel and dentin. ${ }^{20}$ Most of the studies in the related literature have assessed the effects of PBM on HDPSCs on their potential for proliferation, viability, and differentiation, while other studies have assessed the impact of vitamin $\mathrm{D}$ on the potential for differentiation. However, there is no study evaluating the combined effect of photobiomodulation (PBM) and vitamin D on HDPSCs. In the present study, the combination of vitamin D and PBM using 1or $2 \mathrm{~J} / \mathrm{cm}^{2}$ of $810 \mathrm{~nm}$ diode laser had synergistic effect on proliferation and odontogenic activity of HDPSCs through MTT assay and gene expression. The wavelength, power level, and energy density were approved to affect the desired results of cell proliferation. ${ }^{21}$ Limited research studies have approved that LILT reinforces the proliferation of HDPSCs through using diode lasers with different wavelengths and energy densities with a wide range. However, 2 and $4 \mathrm{~J} / \mathrm{cm}^{2}$ are the most commonly researched due to their potential clinical application. ${ }^{22}$ Few studies have mentioned the effect of an $810 \mathrm{~nm}$ diode laser on the angiogenesis and dentinogenesis of HDPSCs. It has been shown that irradiation by $810 \mathrm{~nm}$ has a stimulatory effect on proliferation, dentinogenic genes, and angiogenic genes. In this research, HDPSCs irradiated with $\left(2 \mathrm{~J} / \mathrm{cm}^{2}\right)$ and treated with vitamin D were higher than HDPSCs irradiated with $\left(1 \mathrm{~J} / \mathrm{cm}^{2}\right)$ and treated conjointly with vitamin D in cell proliferation, angiogenic and dentinogenic proteins. While previous study of El Nawam et $\mathrm{al}^{6}$ reported that $810 \mathrm{~nm}$ diode laser with energy density $3 \mathrm{~J} / \mathrm{cm}^{2}$ increased odontogenic genes expression more than $1 \mathrm{~J} / \mathrm{cm}^{2}$, other study of Renno et $\mathrm{al}^{23}$ and Milward et $\mathrm{al}^{24}$ reported that osteoblast and HDPSCs proliferation increased with $810 \mathrm{~nm}$ diode laser. Besides, Soleimani et $\mathrm{al}^{25}$ concluded that higher energy densities ( 4 and $6 \mathrm{~J} / \mathrm{cm}^{2}$ ) enhanced the human bone marrow stem cells differentiation into both neurons and osteoblasts respectively. Contrariwise, Bouvet-Gerbettaz et $\mathrm{al}^{26}$ stated that an energy density of $4 \mathrm{~J} / \mathrm{cm}^{2}$ with an $810 \mathrm{~nm}$ diode laser inhibited the murine bone marrow stem cells proliferation without effect on differentiation. However, comparing with power outputs used in several studies ranging between 20 and $50 \mathrm{~mW}$, such adverse effects may be the consequence of relatively high power $(520 \mathrm{~mW})$. Specific angiogenic and odontogenic genes were exquisite for analysis in this research. LILT with two different parameters $\left(1\right.$ and $\left.2 \mathrm{~J} / \mathrm{cm}^{2}\right)$ and vitamin $\mathrm{D}$ have a positive influence on the angiogenic expression (VEGF) and odontogenic genes (DSPP, BMP-2), which was higher in the group of LILT $\left(2 \mathrm{~J} / \mathrm{cm}^{2}\right)$ treated by vitamin D. DSPP is also active in the mineralization and maturation of dentin, which is strongly expressed in odontoblasts. ${ }^{27}$ This was also consistent with Arany et $\mathrm{al}^{28}$ who stated that LILT with 
$3 \mathrm{~J} / \mathrm{cm}^{2}$ resulted in an increase in odontogenic markers, dentin sialoprotein (DSP), and ALP when used instead of lower $\left(0.03\right.$ and $\left.0.3 \mathrm{~J} / \mathrm{cm}^{2}\right)$ or higher $\left(30 \mathrm{~J} / \mathrm{cm}^{2}\right)$ doses. As for vitamin $\mathrm{D}$, the outcome of the DSPP upregulation in HDPSCs cultured with vitamin D was identical to that in the last research by Tonomura et $\mathrm{al}^{29}$ who stated that HDPSCs cultured with vitamin D increased the level of DSP. Moreover, it was totally different from the research finding by Ritchie et $\mathrm{al}^{30}$ stating that vitamin $\mathrm{D}$ had upregulated osteopontin but had no effect on DSP-PP mRNA in the culture of the rat tooth organ. To validate the odontogenic capacity of HDPSCs, ALP was investigated as an initial indicator for the formation of hard tissue or odontogenic differentiation ${ }^{9}$ in the current research. LILT $\left(2 \mathrm{~J} / \mathrm{cm}^{2}\right)$ with vitamin D enhanced ALP expression and activity of HDPSCs. The beginning of odontogenesis resulted in the formation of a mineralized matrix as soon as HDPSCs were cultured with vitamin D and irradiated by LILT, as evaluated by Alizarin red staining. Although the absence of BMP-2 will affect the other relevant proteins expression, such as DSPP, it is regarded as a non-specific marker for dentinogenesis. ${ }^{31,32}$ BMP2 reinforces secondary dentin bridge formation through the up-regulation of DSPP expression. ${ }^{10}$ The expression of this marker in our analysis is consistent with ManzanoMoreno et $\mathrm{al}^{33}$ who reported that LILT diode laser $940 \mathrm{~nm}$ with the three different groups, $3 \mathrm{~J}, 4 \mathrm{~J}$, and $3 \mathrm{~J}$, enhanced significantly BMP-2 expression in human osteosarcoma cell lines. Likewise, Fujimoto et $\mathrm{al}^{34}$ reported that 1, $91 \mathrm{~J} /$ $\mathrm{cm}^{2}$ with diode laser $830 \mathrm{~nm}$ had a stimulatory effect on BMP-2 gene and protein expression in a mouse osteoblastlike cell line. Also, Nakashima ${ }^{35}$ stated that throughout odontoblast terminal differentiation, BMP-2 expression became highly active, and Iohara et $\mathrm{al}^{36}$ observed that DSPP mRNA expression was reinforced by BMP-2 expression. VEGF plays an important role in angiogenesis and maintains osteoblast function, and is secreted by osteoblastic and endothelial cells. ${ }^{37}$ VEGF is a crucial proangiogenic factor, binding to its cell surface receptor and inducing cascade signals which have a significant effect on the neovascularization process. ${ }^{38}$ In this research, LILT $810 \mathrm{~nm}\left(2 \mathrm{~J} / \mathrm{cm}^{2}\right)$ with vitamin D up-regulated the VEGF expression. Clinical relevance according to these results, LILT and vitamin D will open the therapeutic window in dental tissue regeneration and represent a significant point in the preservation of dental pulp tissue.

\section{Conclusion}

Current research proposed that LILT with vitamin D will have an important influence on the revolution of forthcoming therapeutic applications of vital pulp therapy and regenerative endodontics by enhancing dentin-pulp complex angiogenesis and dentinogenesis, which may have several benefits.

\section{Ethical Considerations}

The protocol of this research was approved by the ethics committee of National Institute of Laser Enhanced Sciences (NILES), Cairo University, Egypt (identification number code 019025). The present research was conducted in collaboration with the Medical Biochemistry and Molecular Biology Department (Tissue culture unit) of the faculty of Medicine, Cairo University. All procedures were performed according to the Declaration of Helsinki 2008 and the patients gave their informed written consent for their enrollment in the research study.

\section{Conflict of Interests}

The authors declare that there is no conflict of interest regarding the publication of the article.

\section{Funding}

The authors received no financial support for the research, authorship, and/or publication of this article.

\section{References}

1. Shilpa PS, Kaul R, Sultana N, Bhat S. Stem cells: Boon to dentistry and medicine. Dent Res J (Isfahan). 2013;10(2):149-54. doi:10.4103/1735-3327.113321

2. Yasui T, Mabuchi Y, Morikawa S, Onizawa K, Akazawa C, Nakagawa T, et al. Isolation of dental pulp stem cells with high osteogenic potential. Inflamm Regen. 2017;37(1): 8. doi: 10.1186/s41232-017-0039-4

3. Posten W, Wrone DA, Dover JS, Arndt KA, Silapunt S, Alam M. Low-level laser therapy for wound healing: mechanism and efficacy. Dermatol Surg. 2005; 31(3):33440. doi: 10.1111/j.1524-4725.2005.31086

4. Woodruff LD, Bounkeo JM, Brannon WM, Dawes KS, Barham CD, Waddell DL, et al. The efficacy of laser therapy in wound repair: a meta-analysis of the literature. Photomed Laser Surg. 2004;22(3):241-247. doi:10.1089/1549541041438623

5. Da Silva JP, da Silva MA, Almeida AP, Lombardi Junior I, Matos AP. Laser therapy in the tissue repair process: a literature review. Photomed Laser Surg. 2010;28(1):17-21. doi: $10.1089 /$ pho.2008.2372

6. El Nawam H, El Backly R, Zaky A, Abdallah A. Low-level laser therapy affects dentinogenesis and angiogenesis of in vitro 3D cultures of dentin-pulp complex. Lasers Med Sci. 2019;34(8):1689-98. doi:10.1007/s10103-019-02804-6.

7. Khanna-Jain R, Vuorinen A, Sándor GK, Suuronen R, Miettinen S. Vitamin D (3) metabolites induce osteogenic differentiation in human dental pulp and human dental follicle cells. J Steroid Biochem Mol Biol. 2010;122(4):13341. doi: 10.1016/j.jsbmb.2010.08.001

8. Woo SM, Lim HS, Jeong KY, Kim SM, Kim WJ, Jung JY. Vitamin D promotes odontogenic differentiation of human dental pulp cells via ERK activation. Molecules and Cells. 2015;38(7):604-609.' doi: 10.14348/molcells.2015.2318.

9. Cho YD, Yoon WJ, Woo K M, Baek JH, Park JC, Ryoo H M. The canonical BMP signaling pathway plays a crucial part in stimulation of dentin sialophosphoprotein expression by BMP-2. J Biol Chem. 2010;285(47): 36369-36376. 'doi: 10.1074/jbc.M110.103093. 
10. Zhang W, Zhang X, Ling J, Wei X, Jian Y. Osteo-/ odontogenic differentiation of BMP2 and VEGF gene-cotransfected human stem cells from apical papilla. Mol Med Rep. 2016;13(5):3747-3754. doi:10.3892/mmr.2016.4993

11. Tilotta F, Brousseau P, Lepareur E, Yasukawa K, de Mazancourt P. A comparative study of two methods of dental pulp extraction for genetic fingerprinting. Forensic Sci Int. 2010;202(1-3):e39-43. doi: 10.1016/j. forsciint.2010.06.019

12. Moussa MS, Hafez S, Sabry D. In Vitro differentiation potential of isolated dental pulp stem cells. Egypt Dent J. 2018;64:223-31. doi:10.21608/edj.2018.77075

13. Huang C, Bao L, Lin T, Lu Y, Wu Y. Proliferation and odontogenic differentiation of human umbilical cord mesenchymal stem cells and human dental pulp cells cocultured in hydrogel. Arch Oral Biol. 2020;109:104582. doi.10.1016/j.archoralbio.2019.104582

14. Mathur A, Loskill P, Shao K, Huebsch N, Hong S, Marcus SG, et al. Human iPSC-based cardiac microphysiological system for drug screening applications. Sci Rep. 2015;5(1):8883. doi:10.1038/srep08883

15. Dominici M, Le Blanc K, Mueller I, Slaper-Cortenbach I, Marini F, Krause D, et al. Minimal criteria for defining multipotent tmesenchymal stromal cells. ISCT Cytotherapy. 2006;8(4):315-7.doi:10.1080/14653240600855905

16. Lim SW, Loh HS, Ting KN, Bradshaw TD, Allaudin ZN. Reduction of MTT to purple formazan by vitamin $\mathrm{E}$ isomers in the absence of cells. Trop Life Sci Res. 2015;26(1):111.

17. Farsi NM, El Ashiry EA, Abdrabuh RE, Bastawi HA, El Meligy OA. Effect of different pulp capping materials on proliferation and odontogenic differentiation of human dental pulp mesenchymal stem cells. Int J Pharm Res Allied Sci. 2018;7(3):209-223.

18. Yang G, Ju Y, Liu S, Zhao S. Lipopolysaccharide upregulates the proliferation, migration, and odontoblastic differentiation of $\mathrm{NG}^{+}$cells from human dental pulp in vitro. Cell Biol Int. 2019;43(11):1276-85. doi:10.1002/ cbin. 11127

19. Duncan HF, Kobayashi Y, Shimizu E. Growth Factors and Cell Homing in Dental Tissue Regeneration. Curr Oral Health Rep. 2018;5(4):276-85. doi:10.1007/s40496-0180194-y

20. Barron MJ, McDonnell ST, MacKie I, Dixon MJ. Hereditary dentine disorders: dentinogenesis imperfecta and dentine dysplasia. Orphanet J Rare Dis. 2008; 3(1): 31. doi: 10.1186/1750-1172-3-31

21. Zaccara IM, Ginani F, Mota-Filho HG, Henriques ÁC, Barboza CA. Effect of low-level laser irradiation on proliferation and viability of human dental pulp stem cells. Lasers Med Sci. 2015;30(9):2259-64. doi: 10.1186/17501172-3-31

22. Borzabadi-Farahani A. Effect of low-level laser irradiation on proliferation of human dental mesenchymal stem cells; a systemic review. J Photochem Photobiol B. 2016;162:57782. doi:10.1016/j.jphotobiol.2016.07.022

23. Renno AC, McDonnell PA, Parizotto NA, Laakso EL. The effects of laser irradiation on osteoblast and osteosarcoma cell proliferation and differentiation in vitro. Photomed
Laser Surg. 2007;25(4):275-80. doi:10.1089/pho.2007.2055

24. Milward MR, Hadis MA, Cooper PR, Gorecki P, Carroll JD, Palin WM. Biomodulatory effects of laser irradiation on dental pulp cells in vitro. In: Proc of SPIE. 2015;(Volpp 930908-930901). doi: 10.1117/12.2077717

25. Soleimani M, Abbasnia E, Fathi M, Sahraei H, Fathi Y, Kaka G. The effects of low-level laser irradiation on differentiation and proliferation of human bone marrow mesenchymal stem cells into neurons and osteoblastsan in vitro study. Lasers Med Sci. 2012;27(2):423-30. doi:10.1007/s10103-011-0930-1

26. Bouvet-Gerbettaz S, Merigo E, Rocca JP, Carle GF, Rochet N. Effects of low-level laser therapy on proliferation and differentiation of murine bone marrow cells into osteoblasts and osteoclasts. Lasers Surg Med. 2009;41(4):291-7. doi: 10.1002/lsm.20759

27. Bègue-Kirn C, Krebsbach PH, Bartlett JD, Butler WT. Dentinsialoprotein, dentin phosphoprotein, enamelysin and ameloblastin, tooth-specific molecules that are distinctively expressed during murine dental differentiation. Eur J Oral Sci. 1998;106(5):963-970. I doi:10.1046/j.0909-8836.1998.eos106510.x

28. Arany PR, Cho A, Hunt TD, Sidhu G, Shin K, Hahm E, et al. Photoactivation of endogenous latent transforming growth factor- $\beta 1$ directs dental stem cell differentiation for regeneration. Sci Transl Med. 2014;6(238):238ra69-. doi:10.1126/scitranslmed.3008234.

29. Tonomura A, Sumita Y, Ando Y, Iejima D, Kagami H, Honda MJ, et al. Differential inducibility of human and porcine dental pulp-derived cells into odontoblasts. Connect Tissue Res. 2007;48(5):229-38. doi:10.14348/molcells.2015.2318

30. Ritchie HH, Park H, Liu J, Bervoets TJ, Bronckers A L. Effects of dexamethasone, vitamin A and vitamin D3 on DSP-PP mRNA expression in rat tooth organ culture. Biochim Biophys Acta. 2004;1679(3):263-71. doi: 10.1016/j. bbaexp.2004.07.004

31. Chen S, Gluhak-Heinrich J, Martinez M, Li T, Wu Y, Chuang $\mathrm{HH}$, et al . Bone morphogenetic protein 2 mediates dentin sialophosphoprotein expression and odontoblast differentiation via NF-Y signaling. J Biol Chem. 2008;283(28): 19359-19370. doi: 10.1074/jbc.M709492200.

32. Yang W, Harris MA, Cui Y, Mishina Y, Harris SE, GluhakHeinrich J. Bmp2 is required for odontoblast differentiation and pulp vasculogenesis. J Dent Res. 2012;91(1):58-64. doi: 10.1177/0022034511424409

33. Manzano-Moreno FJ, Medina-Huertas R, RamosTorrecillas J, García-Martínez O, Ruiz C. The effect of low-level diode laser therapy on early differentiation of osteoblast via BMP-2/TGF- $\beta 1$ and its receptors. $J$ Craniomaxillofac Surg. 2015;43(9):1926-32. doi: 10.1016/j. jcms.2015.08.026

34. Fujimoto K, Kiyosaki T, Mitsui N, Mayahara K, Omasa S, Suzuki N, et al. Low-intensity laser irradiation stimulates mineralization via increased BMPs in MC3T3-E1 cells. Lasers Surg Med. 2010,42(6):519-26.doi:10.1002/1sm.20880

35. Nakashima M. Induction of dentin formation on canine amputated pulpbyrecombinanthumanbonemorphogenetic proteins (BMP)-2and-4. J Dent Res.1994;73(9):1515-22. 
doi: $10.1177 / 00220345940730090601$

36. Iohara $K$, Nakashima $M$, Ito $M$, Ishikawa $M$, Nakasima A, Akamine A. Dentin regeneration by dental pulp stem cell therapy with recombinant human bone morphogenetic protein 2. J Dent Res. 2004;83(8):590-5. doi: $10.1177 / 154405910408300802$

37. De Oliveira TS, Serra AJ, Manchini MT, Bassaneze V, Krieger JE, de Tarso Camillo de Carvalho P, et al. Effects of low level laser therapy on attachment, proliferation, and gene expression of VEGF and VEGF receptor 2 of adipocyte-derived mesenchymal stem cells cultivated under nutritional deficiency. Lasers Med Sci. 2015;30(1):217-23. doi: 10.1155/2015/409347

38. Gerwins P, Sköldenberg E, Claesson-Welsh L.Function of fibroblast growth factors and vascular endothelial growth factors and their receptors in angiogenesis. Crit Rev Oncol Hematol. 2000;34(3):185-94. doi: 10.1007/s10103-014$1646-9$ 